\title{
Bitcoin: digitális szemfényvesztés, vagy a jövő valutája?*
}

\author{
Bugár Gyöngyi - Somogyvári Márta
}

\begin{abstract}
A bitcoin az elmúlt tíz év egyik legérdekesebb pénzügyi innovációjának nevezhetö. Az esszében arra keressük a választ, hogy miért nem terjedt el fizetöeszközként, hogyan vált ehelyett kockázatos befektetési formává. Megvizsgáljuk a bitcoin-technológia müködési mechanizmusát, és bemutatjuk a bitcoin népszerüségét megalapozó ideológiai hátteret. Következtetéseink szerint a bitcoin a mostani formájában nem alkalmas arra, hogy általánosan elfogadott fizetöeszközzé váljon.
\end{abstract}

Journal of Economic Literature (JEL) kódok: E42, G10, O31

Kulcsszavak: bitcoin, kriptovaluta, blockchain, libertariánus gazdaságpolitika

\section{Bevezetés}

Az utóbbi évtized talán egyik legérdekesebb pénzügyi innovációja a bitcoin és más kriptovaluták megjelenése. Ez a fizetőeszköznek szánt befektetési forma ma már mindenki számára elérhető, akár az interneten, akár a Budapesten is megtalálható bitcoin ATM-eken keresztül. Azonban sem az egyszerú felhasználók, de még a pénzügyi szakemberek jó része sincs tisztában a bitcoint megalapozó ideológiával, e kriptovaluta múködési mechanizmusával és a benne rejlő kockázatokkal. Célunk az, hogy bemutassuk azt az elméleti problémát (double spending), amelynek megoldására Nakamoto kidolgozta a bitcoin alapjául szolgáló blockchain-rendszert, és felvázoljuk a bitcoin múködési mechanizmusát, mai szerepét. Rá kívánunk világítani arra az ideológiai háttérre is, ami a bitcoin népszerúségét biztosítja, és fenntartja a bitcoin-közösséget. $E$ területek áttekintésével szeretnénk megválaszolni a címben felvetett kérdést, és kitekinteni a bitcoin jövőbeli felhasználási lehetőségeire. Ezután bemutatjuk a bitcoin technológiai háttereként szolgáló fehér könyvet, a kriptovalutá-

* A jelen kiadványban megjelenő írások a szerzők nézeteit tartalmazzák, ami nem feltétlenül egyezik a Magyar Nemzeti Bank hivatalos álláspontjával.

Bugár Gyöngyi egyetemi docens a Pécsi Tudományegyetem Közgazdaságtudományi Kara Kvantitatív Menedzsment Intézetében. E-mail: bugar.gyongyi@ktk.pte.hu

Somogyvári Márta egyetemi docens a Pécsi Tudományegyetem Közgazdaságtudományi Kara Kvantitativ Menedzsment Intézetében. E-mail: somogyvari.marta@ktk.pte.hu

A kutatást az Innovációs és Technológiai Minisztérium Felsőoktatási Intézményi Kiválósági Programja finanszírozta, a Pécsi Tudományegyetem 4. tématerületi programja - A hazai vállalatok szerepének növelése a nemzet újraiparosításában - keretében.

A magyar nyelvű kézirat első változata 2019. szeptember 14-én érkezett szerkesztőségünkbe.

DOI: http://doi.org/10.25201/HSZ.19.1.132153 
kat megalapozó ideológiát, és rámutatunk a bitcoin jelentőségére. A 3. fejezetben ismertetjük a bitcoint megalapozó blockchain-technológiát és múködési mechanizmusát. A 4. fejezetben megvizsgáljuk, hogy fizetőeszközként, illetve befektetési lehetőségként milyen szerepet játszik a gazdaságban. Az 5. fejezetben rámutatunk elterjedésének korlátaira, ami egyrészt a technológiából, másrészt a szabályozási környezetből adódik. Végül összegezzük a bitcoin jövőjével kapcsolatos meglátásainkat.

\section{A bitcoin-rendszer kialakítása, a bitcoin szerepe és jelentősége}

\subsection{A bitcoin fehér könyve: a rendszer kialakítása}

Satoshi Nakamoto 2008. október 31-én publikálta egy új, innovatív fizetési rendszerre vonatkozó elképzelését egy kriptográfiával foglalkozó levelezólistán. A filantrópiai küldetéstudat által vezérelt szerző kilencoldalas tanulmányában - a legutóbbi pénzügyi világválság legkeményebb évében - egy bankoktól mentes, központi (közvetítő) szereplő nélküli, független és egyenrangú szereplők közötti online fizetési hálózatot ír le (Nakamoto 2008), amely lényegében mindenki számára hozzáférhető. A bitcoin-rendszer minden idők legelső, kriptográfiát alkalmazó, decentralizált fizetési koncepciójának tekinthető (Gábor - Kiss 2018).

A Nakamoto által elképzelt és megvalósított, nyílt forráskódú rendszer nem bizalmon, hanem digitális aláirásokon alapul. A nyílt forráskód révén a rendszer publikus, abba bárki szabadon beléphet, és bármikor ki is léphet belőle. A szerző a hálózatban előállított bitcoint úgy definiálta, mint digitális aláírások láncolatát. Egy tranzakció során az elektronikus érmét tulajdonosa úgy ruházza át a következő tulajdonosra, hogy privát kulcsa segítségével digitálisan aláírja az előző tranzakcióból származó hash- $\mathrm{t}^{1}$, valamint a következő tulajdonos publikus kulcsát, és ezt az érmét reprezentáló aláírás-sorozat végéhez csatolja. A hash-függvények (magyarul hasítófüggvények) olyan informatikában használt eljárások (tulajdonképpen rejtjelezési algoritmusok), amelyekkel bármilyen hosszúságú adatot adott hosszúságúra képezhetünk le. Az így kapott véges adat neve hash (hasító érték). A hash tulajdonképpen egy, az eredeti üzenetet azonosító ellenőrzőkód, egyfajta digitális ujjlenyomat ${ }^{2}$. A kedvezményezett a hitelesség megerősítése céljából ellenőrizheti a digitális aláirásokat. A fentiekben leírt tranzakciók sorozatát az 1. ábrán szemléltetjük.

\footnotetext{
${ }^{1}$ A hash jelentése szó szerinti fordításban: hasadék, darálék, darált hús.

${ }^{2}$ Schaffer József: A Bitcoin ismertetője. Elektronikus feljegyzés, 2014. január 7. http://plastik.hu/2014/01/07/abitcoin-ismertetoje/. Letöltés ideje: 2019. augusztus 14.
} 


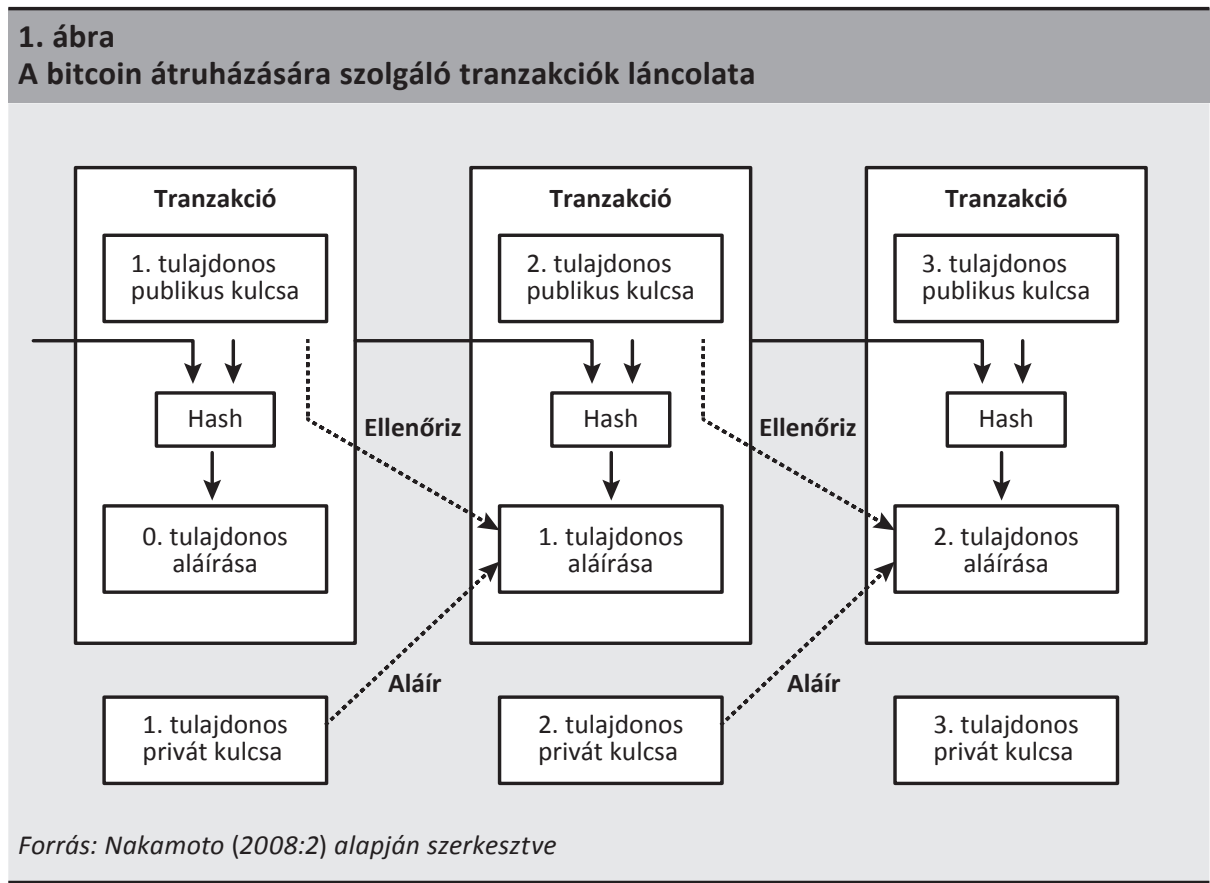

A rendszer múködése szempontjából fontos kihívás annak megakadályozása, hogy egy már elköltött összeget újra el lehessen költeni. Ennek a problémának a megoldására Nakamoto (2008) a tranzakciók nyilvánosságra hozatalát és a hálózat szereplőinek konszenzusán alapuló tranzakcióhitelesítést javasolt. Ezzel ki tudja küszöbölni azt a központi szereplőt, amely az elszámolást végzi, és garantálja a tranzakciók hitelességét.

A tranzakciók nyilvánosságra hozatala egy megosztott nyilvántartási könyv (osztott főkönyv) segítségével történik, amely lényegében a tranzakciókat tartalmazó adatbázis, és bármely szereplő számára elérhető. Ebben az adatok (az egyes tranzakciók) blokkokba vannak rendezve, a hitelesített blokkok pedig láncot alkotnak (blockchain, magyarul blokklánc). A hálózat egyes csomópontjai versenyeznek abban, hogy ki tudja először a soron következő pénzügyi tranzakciókat tartalmazó adatblokkot megfejteni, és a hitelesítést igazoló digitális időbélyegzővel ellátni. Ez egy kellően nehéz matematikai algoritmus alkalmazására épülő kódfejtést jelent (proof-of-work). Ezzel válik igazolhatóvá, hogy egy adott tranzakció résztvevője a tranzakcióban szereplő összeget korábban még nem próbálta elkölteni.

A tranzakciók hitelesítéséért versengő szereplőket Nakamoto (2008) bányászoknak nevezi. A bányászokat az motiválja, hogy a blokkok megfejtéséért bitcoint kapnak cserébe. Alapjában véve így keletkezik a pénz a rendszerben, azaz a blokkokat dekódoló tranzakcióhitelesítők végzik a pénzteremtést. 
A hálózat működtetésének lépéseit Nakamoto (2008:3) a következőképpen írja le:

1) Az új tranzakciók elterjesztése az összes csomópont számára;

2) Minden egyes csomópont egy blokkba gyűjti az új tranzakciókat;

3) Az egyes csomópontok dolgozni kezdenek a blokk megfejtésén;

4) Amint egy csomópont sikeresen megfejti a blokkot, továbbítja azt a többi csomópontnak;

5) A csomópontok csak akkor fogadják el a blokkot, ha minden általa tartalmazott tranzakciót érvényesnek találnak, és nem derül fény arra, hogy egy pénzösszeget újra el akartak költeni;

6) A csomópontok úgy fejezik ki a blokk elfogadását, hogy dolgozni kezdenek a lánc következő blokkján azáltal, hogy elkezdik alkalmazni az azt megelőző, elfogadott blokk hash-értékét.

A rendszer biztonságos múködését az egyes csomópontok többségi konszenzusán alapuló hitelesítési folyamat garantálja. A csomópontok mindig a leghosszabb láncot fogadják el korrektnek, és ennek kiterjesztésén dolgoznak folyamatosan. Ha két csomópont egyidejűleg a következő blokk eltérő változatát osztja meg a többi csomóponttal, akkor bizonyos csomópontokhoz az egyik, míg másokhoz a másik változat érkezhet be először. Ebben az esetben az elsőként beérkező blokkon dolgoznak tovább, de lementik a másikat is arra az esetre, ha az azt tartalmazó blokklánc hoszszabbá válna. Az mindig a soron következő blokk megfejtésével válik nyilvánvalóvá, hogy melyik blokkot kell elvetni, azaz melyik ágon kell továbbhaladni. (Ebből adódik, hogy azok a tranzakciók, amelyek egy rövidebb blokkváltozatban szerepelnek, nem teljesülnek, így azokat újra kell indítani.)

Nakamoto (2008) a rendszer biztonsága szempontjából rámutatott a rendszerben meglévő ösztönzőrendszer fontosságára. Minden blokk első tranzakciója speciális tranzakció, amely egy új, a blokk megfejtőjének tulajdonába kerülő virtuális pénzt (bitcoint) teremt. Ez motiválja a csomópontokat a rendszer támogatására, és ugyanakkor biztosítja a virtuális pénzegységek forgalomba kerülését. Egy blokk megfejtéséért járó „,juttatás” tulajdonképpen a kódfejtésre használt számítógép-erőforrások (CPU-kapacitások) és a ráfordított elektromos energia megtérülését szolgálja. Ez a rendszerbe beépített ösztönző Nakamoto (2008) meggyőződése alapján segíti azt, hogy a rendszer szereplői kövessék a szabályokat. Ha megjelenik a hálózatban egy kapzsi „támadó”, aki több CPU-kapacitást birtokol, mint a becsületes csomópontok együttesen, akkor választhat, hogy erre támaszkodva - a rendszer szereplőinek megtévesztésével - visszaszerzi az addigi befizetéseit, vagy erőforrásait arra használja, hogy új pénzt teremtsen. Nakamoto (2008) szerint ebben az esetben fel kell ismer- 
nie, hogy jövedelmezőbb számára, ha betartja a „játékszabályokat”, amelyek abban támogatják, hogy így több új bitcoinhoz juthat, mint a többi szereplő együttesen.

\section{2. ábra \\ A hagyományos pénzügyi közvetítői rendszer és a bitcoin titoktartási modelljének összehasonlítása}

Hagyományos modell
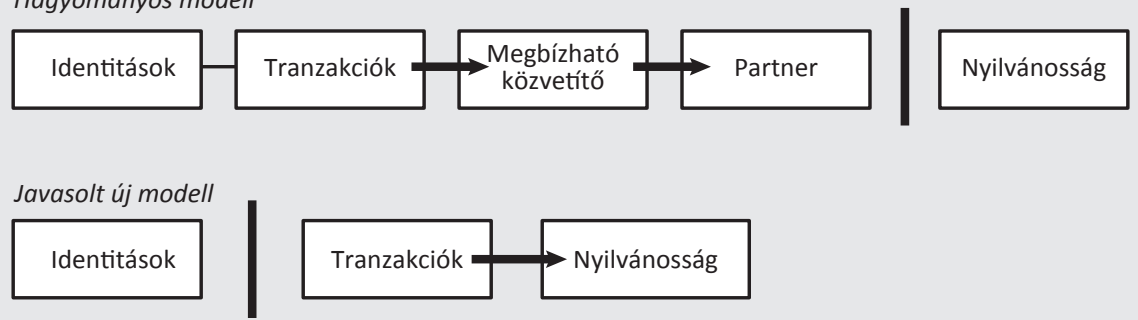

Forrás: Nakamoto (2008:6) alapján szerkesztve

Nakamoto (2008) fizetési rendszere a tranzakciók nyilvánosságra kerülése tekintetében is eltér a hagyományos banki titoktartási modelltől. A hagyományos banki modell a résztvevő felek, valamint a megbízható harmadik fél (közvetítő bank) számára korlátozott hozzáférést biztosít az információkhoz, a nyilvánosságot pedig egy túzfallal teljesen kizárja az információáramlás folyamatából. A tranzakciók nyilvánossá tételének szükségessége kizárja az előző modellt, de a személyes adatok védelme, sőt az anonimitás - az információáramlás más ponton történő megszakításával - fenntartható. A publikus kulcsok ugyanis nem névre szólók. Az arra vonatkozó információ, hogy valaki küld egy másik személynek (identitásnak) egy összeget, nyilvánosan elérhető anélkül, hogy a tranzakció résztvevői azonosíthatók lennének. Ez hasonlít a tőzsdék által követett titoktartási elvekhez, ami abban áll, hogy nyilvánosságra hozzák az egyedi tranzakciók méretét és idejét, a bennük részt vevő felek azonban nem ismertek. A két modell közti különbséget a 2. ábrán szemléltetjük.

\subsection{A bitcoint megalapozó filozófiák}

Nakamoto bitcoint megalapozó tanulmánya látszólag egy, az online átutalási rendszerek technikai problémáival foglalkozó tanulmány, amely ki akarja küszöbölni a bankokat és a pénzügyi intézményeket az átutalási folyamatból. A bitcoin és a kriptopénzek elterjedése azonban nem a technológiának, hanem a technológia által képviselt ideológiának köszönhető. Ennek az ideológiának két fontos eleme a mindenfajta állami szabályozás, így a központi bankok és a monetáris szabályozás megkérdőjelezése, illetve a digitális létforma elsőbbségét hirdető cyber-libertarianizmus. 
Az USA ultrakonzervatív köreinek felfogása szerint az állam autoriter (Levin 2009), s mindenféle állami beavatkozás, így például a szociális transzferek, így az alanyi jogon járó egészségbiztosítás is, az egyéni szabadság megsértését jelentik. A bitcoin-közösségben ezek a gondolatok újra meg újra felvetődnek, s innen adódik a bitcoin mozgalmi jellege is, amivel újabb meg újabb bitcoin-hívőket tudnak elérni. Eszerint minden kormányzás elvetendő, csak a piaci erők jók, amelyekkel meg lehet akadályozni a hatalom koncentrációját, ami, ha az állam, a kormányzat rendelkezik vele, akkor túlzott hatalmi fókuszhoz vezethet. Kritizálják a monetáris politika vitelét, valamint összeesküvés-elméletekre hivatkozva a Fed és a központi bankok tevékenységét is (Rothbard 2002, Mullins 1992). E szélsőséges nézetek szerint (lásd Golumbia 2016) az infláció és a defláció nem gazdasági okokra vezethető vissza, hanem a központi bankok tevékenységének eredménye. Ez a gondolatkör alapozza meg az inflációtól mentes pénz megteremtésének igényét a bitcoin algoritmusában.

A cyber-libertarianizmus a digitális létforma elsődlegességét hangoztatja, s ez nemcsak a bitcoin hívei, hanem sokszor a digitális világ szereplői számára is az egyetlen elfogadható világnézet. Ennek egyik megnyilvánulása az internet abszolút szabadságának védelmezése. A valódi és egyedül fontos szakértelem a cyber-libertariánusok számára a digitális technológiákra vonatkozik, s mivel minden visszavezethető IT-folyamatokra és IT-algoritmusokra, ha valaki ezekhez nem ért, akkor nincs joga véleményt mondania (Golumbia 2016). Így a bitcoinnal kapcsolatos minden olyan kritikai észrevétel, amely gazdasági, társadalmi vonatkozásokat emel ki, diszkvalifikálódik a bitcoin hívei előtt.

\subsection{A bitcoin jelentősége a kriptovaluták között}

\subsubsection{A kriptovaluták típusai}

A kriptovaluták két fő csoportját a saját blockchainnel rendelkező digitális pénzek (digital coin) és a már meglevő blockchainre épített tokenek alkotják. Az első csoportot is két részre szokták osztani, ide tartozik a bitcoin, amely ki tudta használni a piacra először belépő szereplők innovációs előnyét, és máig a legjelentősebb kriptovaluta, illetve azok az alternatív kriptovaluták, az altcoinok, amelyek vagy a bitcoin leszármazottai, vagy teljesen új blockchain-algoritmusra épülnek.

Hogyan jöhetnek létre új kriptovaluták a bitcoinból? A bitcoin nyílt forráskódú, osztott főkönyvü, vagyis blockchain-szoftverre épül, ami azt jelenti, hogy lehetőség van a szoftver kódjának megváltoztatására. Amennyiben ezzel a változtatással nem ért egyet az adott blockchain közössége, akkor akár véglegesen kettéválhat a blockchain (ezt nevezik „fork"-nak). Az új kódra épülő blockchain - ami azelőtt a bitcoin része volt, ezután önálló, a bitcointól független életet él. A kód megváltoztatásának az egyik célja az, hogy új tulajdonságokkal ruházzák fel a szoftvert, így jött létre a tranz- 
akciók sebességének megnövelésére alkalmas litecoin. Arra is lehetőség van, hogy alapvető változtatásokat hajtsanak végre a kódon, megnövelve például a blokkok méretét 1MB-ról 8MB-ra, ez vezetett a bitcoin cash kialakulásához. Találunk olyan altcoinokat is, amelyek nem a bitcoin leszármazottai, hanem teljesen új blockchainre épülnek, mint az Omni, az Ether vagy a Ripple.

A kriptovaluták második csoportját az ún. tokenek alkotják. A tokenek nem rendelkeznek külön blockchainnel, hanem olyan platformokat használnak (ilyen a saját altcoinra, az Etherre épülő Ethereum), amelyek lehetővé teszik, hogy a platformok saját blockchain-architektúrájára épülő applikációkkal (DApp) hozzanak létre másodlagos, digitális „kriptopénz-helyettesítő” eszközöket. Ez a folyamat sokkal egyszerúbb, mint a saját blockchain kialakítása. A forgalomba hozáshoz meghirdetik az ún. ICO-t (Initial Coin Offering) egy White paper (fehér könyv) formájában. A tokenek jelképezhetnek valamilyen szolgáltatást, amelyhez a projekt indulása vagy sikeressége esetén hozzá lehet férni, vagyis a token kibocsátása ilyenkor a közösségi finanszírozás új formájaként fogható fel, de gyakran ezeket is befektetési céllal vásárolják.

Jellemzően azok a tokenek népszerúek, és azok árfolyama éri el a kibocsátáskori értékük sokszorosát, amelyek a blockchain-technológia továbbfejlesztését túzik ki célul. Az IOTA ${ }^{3}$ célja egy új filozófiára épülve a tranzakciók lebonyolításának felgyorsítása, az NXt a kriptovaluták elleni támadásokat szeretné kivédeni egy új hitelesítési módszerrel. A cryptocompare.com weboldalon felsorolt 1394 token több mint 90 százaléka a kibocsátáskori értékét rövid idő alatt elveszti, néhány hónap múlva már csak töredékét éri. Az Ázsiában, elsősorban Koreában és Kínában népszerű, Ponzi-sémára épülő, havi 9-18 százalék kamatot ígérő PLUS Token összeomlása 2019 júniusában egyes becslések szerint 3,5 milliárd dollár értékú kárt okozott a befektetőknek (Emsley 2019).

\subsubsection{A legfontosabb kriptovaluták piaci kapitalizációja}

A coinmarketcap.com 2019. augusztus 24-én csaknem 2500 kriptovalutát tartott számon. Nap mint nap generálnak újabb és újabb kriptovalutákat, és a legtöbb viszonylag rövid életú. A bitcoin a legnagyobb kriptovaluta, a piaci dominanciája csaknem 70 százalékos, ami árfolyamtól függően egy 180 milliárd dollár körüli piaci kapitalizációt jelent. A bitcoint követő második legnagyobb kriptovaluta, az Ethereum 20 milliárd dolláros, a Ripple, ami egy centralizált, egy cég kezében összpontosuló blockchain a bankközi átutalások meggyorsítására, 11 milliárd dolláros piaci kapitalizációval rendelkezik. Vajon mit jelent egy kriptovaluta esetében az USD-ben kifejezett piaci kapitalizáció? Definíció szerint a forgalomban levő kriptovaluták (coinok vagy tokenek) száma megszorozva a piaci árral. Ez a számítási módszer lemá-

\footnotetext{
${ }^{3}$ A IOTA szakít a blockchainnel és a hitelesítést gráfok segítségével végzi (DAG: irányított körmentes gráf). Nincs szükség bányászatra, így az egyes tranzakciók energiafelhasználása elenyésző, a rendszer sokkal gyorsabb és skálázhatóbb, mint a blockchain. Popov, S.: The Tangle. 2018. April 30, Version 1.4.3. https://assets. ctfassets.net/r1dr6vzfxhev/2t4uxvslqk0EUau6g2sw0g/45eae33637ca92f85dd9f4a3a218e1ec/iota1_4_3.pdf
} 
solja az értékpapírok piaci kapitalizációjának definícióját. Miután az egyes valuták esetében alkalmazott mutatószámok (átváltási árfolyam, vásárlóerő, infláció stb.) nem alkalmazhatók a kriptovalutákra, már önmagában ennek az indikátornak az alkalmazása is megkérdőjelezi a kriptovaluták pénzjellegét.

\section{A bitcoin technológiai háttere}

\subsection{Blockchain (osztott fökönyv)-technológia}

A blockchain a bitcoin legfőbb technológiai újítása. ${ }^{4}$ Egy megosztott, nyilvános főkönyvként müködik, amely rögzíti az összes bitcoin-tranzakciót. Ez biztosítja a rendszer összes szereplője számára a nyilvánosságot és a transzparenciát. A blokklánc tulajdonképpen egy folyamatosan növekvő, a tranzakciókat tartalmazó adatblokkokból álló lista, amelyben az egyes blokkokat a hamisítást és módosítást kizáró módon kötik össze.

A digitálisan rögzített adatblokkokat egy lineáris láncban tárolják. A tranzakciókat tartalmazó adatblokkokat egy hash-függvény segítségével titkosítják (kriptográfiailag kódolják) és időbélyegzővel látják el. Amikor egy bányász új blokkot hoz létre, akkor ez tartalmazza az előző blokk hash-ét, így a blokkok - a legelsőként létrehozott, ún. genezis-blokktól kezdődően és a legújabb blokkig bezáróan - egy időben rendezett láncot alkotnak. Ez a folyamat újra meg újra ismétlődik, ezáltal növekszik a hálózat.

A blokklánc minden egyes blokkja tartalmaz adatokat (ilyenek például a bitcoin-tranzakciókra vonatkozó adatok), blokkfejlécet, blokkazonosítót és Merkle-fát.

- A blokkfejléc az adott blokkra vonatkozó metaadatokból ${ }^{5}$ áll. Ezek a következők: (a) a blokkot időben megelőző blokk hash-értéke, amely az előző blokk azonosítására szolgál; (b) a blokkot megfejtő bányász azonosítására szolgáló adatok; (c) a blokkban foglalt tranzakciókat összegző adatstruktúra, amely Merkle-fa-gyökérként ismert.

- A blokkazonosító lényegében az a hash-érték, amely az adott blokk egyértelmü azonosítására szolgál.

- A Merkle-fa a blokk tranzakcióinak összefoglalására hivatott. A „fa” kifejezés a számítástechnikában egy elágazó adatszerkezet leírására használatos. A Merkle-fákat általában fejjel lefelé ábrázoljuk, azaz "gyökerük” van az ábra tetején, míg „leveleik" a diagram alján. A Merkle-fa szerepe, hogy a blokkban szereplő tranzakciókból egy átfogó digitális ujjlenyomatot hozzon létre, és így hatékony eljárást biztosítson

\footnotetext{
${ }^{4}$ Az alfejezet megírásában két forrásra támaszkodtunk: a Blockchain Technologies honlapján közzétett információkra (https://www.blockchain-technologies.com) és Andreas M. Antonopoulos „Mastering Bitcoin” nyílt kiadású könyvének „Bitcoin fejlesztőknek” címmel, elektronikusan hozzáférhető fordítására (https:// bitcoinbook.info/wp-content/translations/hu/book.pdf).

${ }^{5}$ A metaadat (angolul metadata) az adatra vonatkozó adat.
} 
annak ellenőrzésére, hogy egy adott tranzakció valóban szerepel-e a blokkban. A Merkle-fa csomópontpárok rekurzív hash-elésével épül fel egészen addig, amíg már csak egy hash, az úgynevezett gyökér vagy Merkle-gyökér marad.

A bitcoin-blokklánc technológiájának legfontosabb jellemzői az alábbiak:

- Konszenzus: arra utal, hogy a hálózat valamennyi anonim részvevője egyetért a hálózat szabályainak követésében, azaz elfogadja, hogy a blokklánc-környezetben „csak egy igazság létezik”. Ehhez a résztvevők 51 százalékának egyetértése szükséges. Ebből adódik, hogy megfelelő számítási kapacitással, amennyiben a csomópontok 51 százalékát egy szereplő uralja, meghekkelhető a blokchain.

- Megosztott adatfeldolgozás: azt fejezi ki, hogy nincs központi csomópont az adatok feldolgozására és elosztására, minden csomópont függetlenül feldolgozhatja és továbbíthatja a hálózat számára a már hitelesített adatokat.

- Információtárolási képesség: azt jelenti, hogy a technológia alkalmas a tranzakciók adatainak és a hozzájuk kapcsolódó információknak a rögzítésére és megőrzésére.

- Tranzakciók eredetének azonosíthatósága: arra utal, hogy minden tranzakció és ahhoz füződő aktivitás rögzítésre kerül, így teljes mértékben nyomon követhető.

- Megmásíthatatlanság: azt fejezi ki, hogy a hálózat egyetlen résztvevője sem módosíthat egy már rögzített tranzakciót. A hibás rekord nem törölhető, és mindig látható, ha egyszer rögzítették. A hiba kijavítása a hibás tranzakciót ellentételező, új tranzakció indításával lehetséges.

- Nyilvános hozzáférhetőség: azt jelenti, hogy a rendszer valamennyi szereplője korlátozás nélkül kapcsolódhat a hálózathoz, és elérheti a blokkláncban tárolt adatokat.

\subsection{SHA-256 algoritmus}

Az SHA, a Secure Hash Algorithm (magyarul biztonságos hasító algoritmus) kifejezés rövidítése. Az eljárás a kriptográfiában (titkosításban) használt legelterjedtebb hasító algoritmusok egyike. Az SHA az Egyesült Államok Nemzeti Szabvány- és Technológiai Hivatala (NIST: National Institute of Standards and Technology) által kibocsátott szabványos eljárások összefoglaló elnevezése, amelyek egyike a bitcoin esetében alkalmazott SHA-256 algoritmus. Bár a hasítófüggvények a számítástechnikában már az 1950-es évek elején megjelentek, csak az 1980-as évek legvégén - az elektronikus aláírás megjelenésével - terjedtek el igazán (Buttyán - Vajda 2012).

Az SHA első változatát (SHA 1) 1993-ban fejlesztették az Egyesült Államok rádiótechnikai jelhírszerzéssel foglalkozó szervezetének (NSA: National Security Agency) felügyelete alatt. Ez 160 bit hosszúságú üzenetkivonatot képez, amelyet ezt követően a digitális aláírás algoritmusban használhatunk. A bitcoin esetében alkalmazott 
SHA-256 hasonló elvek alapján múködik, azonban lényegesen nagyobb adatmenynyiséget képes kezelni. A bemenete (a továbbítandó üzenet) $2^{64}-1$ bit hosszúságú lehet, amelyet a feldolgozás során 512 bites blokkokra osztanak. Az output mérete (a kapott hash/hasító érték) összességében 256 bit hosszúságú és 8 darab 32 bites blokk alkotja ${ }^{6}$. Az SHA-256 elnevezés tehát az algoritmus alkalmazása során az outputként kapott hash-érték bitben megadott méretére utal.

\subsection{Proof-of-work}

A proof-of-work (magyarul munkabizonyíték) olyan számérték, amelynek előállítása jelentős számítási kapacitást igényel. A bitcoin esetében a bányászok az SHA-algoritmust használják arra, hogy olyan hash-értéket találjanak, amely megfelel a hálózat egészére vonatkozó nehézségi szintnek (Antonopoulos 2016).

A proof-of-work végrehajtása a bitcoin esetében lényegében egy fent említett érték keresését foglalja magában, amelyre alkalmazva az SHA-256 algoritmust, olyan hasító értéket kapunk, amely meghatározott számú zéró bittel kezdődik. Az algoritmus lépésszáma - az előírt zéró bitek számának függvényében - exponenciális, a megoldás helyessége azonban egyetlen hash végrehajtásával ellenőrizhető (Nakamoto 2008). Ez konkrétan úgy zajlik, hogy a megfelelő blokk megfejtése során a bányász az előző hash mögé ír egy értéket (nonce), majd ezt egészen addig növeli, ameddig az adott blokk így keletkező hash-értéke el nem éri az elvárt zéró bitek számát (a folyamat múködését a 3. ábra illusztrálja). Amennyiben a megfejtés sikeres, az így létrejövő új blokk csak a fenti munka újbóli elvégzésével változtatható meg. Ha időközben újabb blokkok lépnek be a láncba, akkor egy adott blokk megváltoztatása egyúttal a blokkot követő minden újabb blokk megfejtését is megköveteli.

Fontosnak tartjuk megemlíteni, hogy a kriptovaluták esetében a blokklánc-hálózat múködtetésében a proof-of-work mellett az - utóbbi időben egyre népszerúbb ún. proof-of-stake eljárás is használatos. Ebben az esetben a következő blokk előállítója a véletlen és a vagyoni helyzet vagy életkor (stake: magyarul részesedés) kombinációján alapuló kiválasztás eredménye. Ennek az az előnye, hogy felgyorsítja a rendszer múködését, és kiküszöböli azt a veszteséget, amely azokat a bányászokat éri, akik ugyan elkezdik a számításokat, de más megelőzi őket, és így nem kapnak bitcoint. Ezzel szemben a proof-of-work alapú kriptovaluták esetében, mint amilyen a bitcoin is, az új blokk előállítása bányászaton, azaz egy számításigényes algoritmus sikeres végrehajtásán alapul.

${ }^{6}$ A fentiekhez lásd bővebben: Kathi (2009).

${ }^{7}$ https://blockgeeks.com/guides/proof-of-work-vs-proof-of-stake/ 


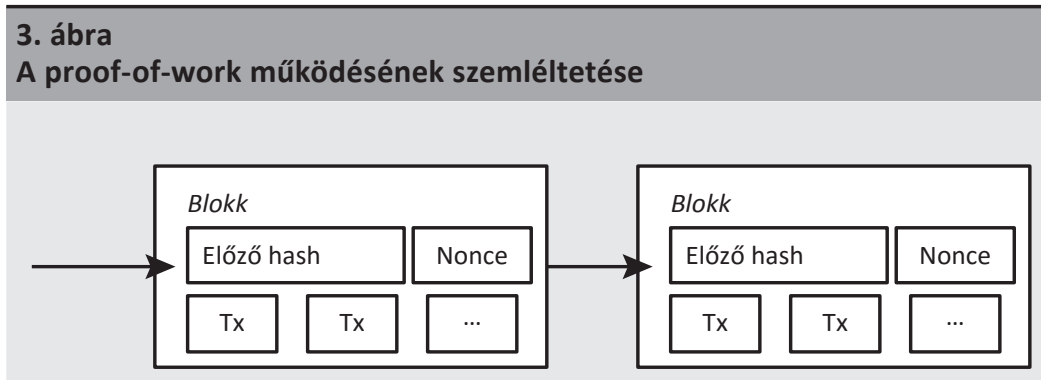

Forrás: Nakamoto (2008:3) alapján szerkesztve

\subsection{A rendszer szereplői, múködtetése}

A blockchaint müködtető rendszer alapvető szereplői a csomópontok (node), amelyek lehetnek bányászok (miner) és felhasználók (user). Erre nagyon sok közvetítő is ráépül, ami lehetővé teszi, hogy a számítástechnikai tudással és technikai háttérrel nem rendelkezők is hozzáférjenek a kriptovalutákhoz. A működés során ahhoz, hogy egy felhasználó bitcoin-tranzakciót tudjon indítani és fogadni, szüksége van egy elektronikus pénztárcára (wallet), ami általában egy ingyenesen letölthető alkalmazás. A tranzakció hitelesítése az ezzel foglalkozó bányászok számítógépén történik, majd az így létrejött új blokkot az egész hálózatnak el kell fogadnia, és az hozzáfüződik az utolsó blokkhoz, megnövelve a teljes blockchain méretét. Ahhoz, hogy valaki részt vegyen a hálózatban, nem szükséges a teljes blockchaint a számítógépén tárolnia. A nemcsak a bitcoinhoz, de más kriptovalutákhoz történő hozzáféréssel rendelkezők száma 2019 első negyedévében mintegy 36 millió felhasználó volt (Tassev 2019). Ezzel szemben azoknak a számítógépeknek a száma (full node), amelyek tárolják a teljes bitcoin-blockchaint 9000 körül volt 2019 augusztusában, és az utóbbi két évben folyamatosan csökkent. ${ }^{8}$ Ez a csökkenés érthető, hiszen semmilyen anyagi előnyt nem jelent a teljes bitcoin-blockchain futtatása, miközben a blokkok száma folyamatosan növekszik. A teljes, a generikus blokkot is tartalmazó blockchain mérete 2019 első negyedévére elérte a 226 GB-ot. A teljes csomópontot üzemeltetők jórészt már nem azok az idealisták, akik lázadnak a kormányok és központi bankok által irányított monetáris rendszer ellen, hanem a bányászok és a befektetők. A hitelesítés folyamata, amelyet a bányászok végeznek el, a blockchain méretének növekedésével egyre nagyobb számítási kapacitást és specializált hardvert és szoftvert igényel. Ennek hatására megindult egy koncentrációs folyamat. A legnagyobb szereplő a piacon a kínai BitMain cég, amely, amellett, hogy a legnagyobb specializált hardvergyártó és szoftverfejlesztő, a bitcoin-bányászat több mint 20 százalékát bonyolítja le. 2019 elejére a nagy energiaigényű bányászat jó része, mintegy 70 százaléka Kínában összpontosult, azokra a területekre, ahol a kiépített

\footnotetext{
${ }^{8}$ https://bitnodes.earn.com/dashboard/?days $=730$
} 
villamosenergia-termelő kapacitások kihasználatlansága miatt alacsonyak az energiaárak (Tuwiner 2019). Az 1 bitcoin kibányászásához szükséges energia- és egyéb költségek 2019-ben Kínában 507 és 4562 dollár között mozogtak, a villamosenergia árától függően. ${ }^{9} \mathrm{Ez}$ a helyzet a jövőben alapvetően meg fog változni, miután Kína a kriptovaluta-tőzsdék felszámolása után a bányászatot is nemkívánatos tevékenységként listázta, s minden bizonnyal be fogja tiltani (Brenda - Alun 2019).

A kriptovaluták köré ma már egész iparág épült olyan szolgáltatókból, amelyek lehetővé teszik a kriptovaluta vásárlását „valódi” nemzeti fizetőeszköz ellenében, illetve a kereskedést a kriptovalutával a kriptovaluta-tőzsdéken, platformokat nyújtanak a tokenek kibocsátásához és a különböző applikációk kifejlesztéséhez, kézben tartják a befektetók számláit, elemzik az egyes kriptovaluták árfolyamát.

A kriptovaluták regionális elterjedését tekintve az észak-amerikai régióban összpontosul a piaci szereplők 27 százaléka, itt zajlik a tranzakciók 18 százaléka, itt található a pénztárcák 39 százaléka. A második legjelentősebb szereplő Európa, de jelentős növekedés várható Ázsia csendes-óceáni régiójában, különösen Japánban. ${ }^{10}$

\section{A bitcoin szerepe és jelentősége a gazdaságban}

\subsection{A bitcoin mint fizetőeszköz}

A bitcoin több mint egy évtizedes fennállása alatt nem az eredetileg neki szánt szerepet töltötte be. A bitcoinnal való fizetés ugyanis nem vált mindennapi gyakorlattá, fizetőeszközként történő elfogadása inkább kuriózumnak számít. Ez nyilvánvalóan a szélsőséges árfolyamingadozásának köszönhető. Teljesen érthető, ha a kereskedők nem hajlandók (sőt nem is tudják) kifejezni egy olyan valutában a termékük értékét, amelynek árfolyama nem stabil.

Említésre érdemes még ebben az összefüggésben, hogy a bitcoin-tranzakciók átfutási ideje más fizetési módokéval (Paypal, hitelkártyák) szemben magas. Ez a rendszer túlterheltsége esetén nagymértékben megnövelheti a tranzakciós díjakat. Ez jelenleg azért fontos szempont, mert a bitcoinnal történő fizetés során - a bank- és hitelkártyás vásárlásokkal szemben - a vevő fizeti a tranzakciós díjat (Gábor - Kiss 2018). Ilyen feltételek mellett nem túnik valószínűnek a közeljövőben annak elterjedése, hogy bitcoinért vásároljunk kisebb értékű cikket (például könyvet vagy kávét).

A bitcoin besorolását a mai napig számos bizonytalanság övezi. Az amerikai határidős árutőzsdét felügyelő szerv (CFTC ${ }^{11}$ ) áruként határozza meg, az amerikai adóhatóság $\left(\mathrm{IRS}^{12}\right)$ pedig tulajdonjogot megtestesítő eszközként tekint rá. Az amerikai

\footnotetext{
${ }^{9} \mathrm{http}: / /$ www.chinacryptonews.com/industry/chart-bitcoin-mining-cost-china-cheapest/

${ }^{10} \mathrm{https}$ ://www.fortunebusinessinsights.com/industry-reports/cryptocurrency-market-100149

${ }^{11}$ Commodity Futures Trading Commission

12 Internal Revenue Service
} 
értékpapír-felügyelet ( $\mathrm{SEC} \mathrm{C}^{13}$ ) bizonyos esetekben értékpapírként sorolja be (Chohan 2017), az Európai Központi Bank pedig konvertibilis decentralizált virtuális valutaként kezeli (Gábor - Kiss 2018, Bánfi 2018).

Gábor és Kiss (2018) kriptovalutákról írt tanulmányukban hangsúlyozzák a kriptovaluta kifejezés félrevezető mivoltát, miszerint ez azt sugallhatja, hogy azok a tradicionális valuták egy alkategóriáját képezik. Véleményük szerint - amellyel abszolút egyetérthetünk - egy teljesen egyedi, új eszközcsoportról van szó.

\subsection{A bitcoin mint befektetés}

Mivel a bitcoin a pénz funkcióját csak korlátozottan képes betölteni, ${ }^{14}$ érdemes megvizsgálni, milyen lehetőséget tartogat számunkra, ha befektetési eszközként tekintünk rá. A bitcoin-árfolyam alakulásának vizsgálatához a Yahoo Finance oldalról letöltöttük a dollárban kifejezett napi záró árfolyamait a 2012. szeptember 1. és a 2019. szeptember 1. közötti, hétéves periódusra. Az árfolyam változását a 4. ábra mutatja.

A vizsgált időszakban a bitcoin napi árfolyama közel 10 dolláros értékről 9578 dollárra nőtt, azaz nagyjából 960-szorosára emelkedett. Nem szabad azonban megfeledkezni arról, hogy ez a rendkívülinek számító növekedés kiugróan magas volatilitással, azaz rendkívül nagy kockázattal párosult. Az ábrán jól látható, hogy a bitcoin árfolyamának növekedése 2017-ben vett igazán komoly lendületet, amikor a kezdeti kb. 1000 dolláros értékről 19340 dolláros ár fölé emelkedett (ami nagyjából 1900 százalékos (!) éves hozamnak felel meg). ${ }^{15}$ Ezt követően az árfolyam erőteljes zuhanásba kezdett, amit a bitcoin-szkeptikusok úgy interpretáltak, hogy „,kipukkadt a lufi” (András 2019), azonban az árfolyam a 3000 dollár körüli mélypontot követően ismét emelkedésbe kezdett, és újra 10000 dollár fölötti értéket ért el.

\footnotetext{
${ }^{13}$ Securities and Exchange Commission

${ }^{14}$ Ennek a kérdésnek a kifejtésével a tanulmányban nem foglalkozunk. A témához kapcsolódóan Bánfi (2018) írását érdemes elolvasni.

${ }^{15}$ Valójában a bitcoin eddigi története során a legmagasabb árfolyamértéket, amely 20089 USD/BTC volt, 2017. december 17-én érte el (https://coinmarketcap.com/currencies/bitcoin/historical-data/).
} 


\section{4. ábra}

A bitcoin napi árfolyamának alakulása 2012. szeptember 1. és 2019. szeptember 1. között

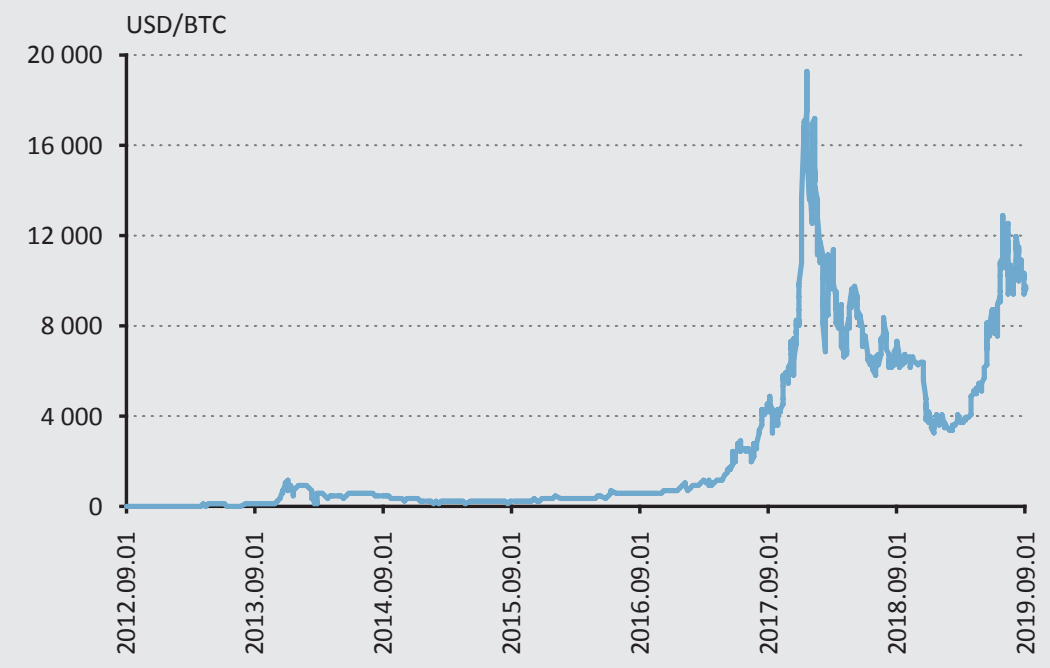

Forrás: A Yahoo Finance adatbázisa alapján szerkesztve ${ }^{16}$

A bitcoin befektetési szempontból történő megítélése jövedelmezőségi és kockázati profiljának együttes elemzésén alapulhat. Ebből a célból a rendelkezésre álló napi árfolyamokból először napi hozamokat számítottunk, majd az egyes évekre vonatkozó napi átlaghozamok felhasználásával - a hétéves periódus minden egyes évére vonatkozóan - meghatároztuk az éves effektív hozamot. Kockázati mértékként a hozamok szórását alkalmaztuk. Ebben az esetben először a hozamok idősorának felhasználásával az egyes évekre vonatkozóan napi szórást számoltunk, majd a kapott napi szórás értékeket éves értékekké konvertáltuk. Eredményeinket az 1. táblázatban foglaljuk össze. A táblázat utolsó sorában a kockázat egységére eső hozamot is feltüntettük.

\footnotetext{
${ }^{16} \mathrm{https}$ ://finance.yahoo.com/quote/BTC-USD/history?p=BTC-USD
} 


\section{1. táblázat}

A bitcoin éves effektív átlaghozamának és kockázatának alakulása 2012. szeptember 1. és 2019. augusztus 31. között

\begin{tabular}{|c|c|c|c|c|c|c|c|}
\hline Periódus & $\begin{array}{c}2012 / 9 / 1- \\
2013 / 8 / 31\end{array}$ & $\begin{array}{l}2013 / 9 / 1- \\
2014 / 8 / 31\end{array}$ & $\begin{array}{l}2014 / 9 / 1- \\
2015 / 8 / 31\end{array}$ & $\begin{array}{l}2015 / 9 / 1- \\
2016 / 8 / 31\end{array}$ & $\begin{array}{l}2016 / 9 / 1- \\
2017 / 8 / 31\end{array}$ & $\begin{array}{l}2017 / 9 / 1- \\
2018 / 8 / 31\end{array}$ & $\begin{array}{l}2018 / 9 / 1- \\
2019 / 8 / 31\end{array}$ \\
\hline Éves hozam (\%) & 2294,27 & 11741,89 & $-37,82$ & 197,23 & 968,28 & 130,23 & 75,13 \\
\hline Hozam szórása (\%) & 102,95 & 390,02 & 71,53 & 57,61 & 71,19 & 97,9 & 73,54 \\
\hline Hozam/Kockázat & 22,29 & 30,11 & $-0,53$ & 3,42 & 13,60 & 1,33 & 1,02 \\
\hline
\end{tabular}

Forrás: A Yahoo Finance adatbázisa alapján számítva

Az 1. táblázatból kiolvasható, hogy mind a hozamokban, mind a hozzájuk kapcsolódó kockázat értékeiben tükröződik az a szélsőséges ingadozás, amely az árfolyamváltozás profilja alapján már kirajzolódni látszott. Az éves átlaghozam -38 százalék és 11742 százalék között mozog (az utóbbi érték, amely tulajdonképpen napi 1,3 százalékos átlaghozamnak felel meg, nem elírás!). A hozam szórásával mért éves kockázat ugyanakkor 58 és 390 százalék között mozog. Összehasonlításképpen: ez utóbbi mutató az S\&P 500 részvényindex esetében általában évi 10 és 20 százalék közé tehető (lásd Misik 2018:70). Az egységnyi kockázatra eső hozam, amely a Sharpe-mutatóhoz hasonlóan a befektetési teljesítmény egyfajta mérőszámának tekinthető, ${ }^{17}$ szintén elég széles skálán mozog. Nevezetesen vizsgálatunkban $-0,5$ és 30 közötti értékeket vesz fel. ${ }^{18}$ Míg az előbbi az árfolyamcsökkenési tendenciából következő veszteségre mutat, addig az utóbbi egyedülállóan magas érték a szélsőségesen nagy éves átlaghozam hatását fejezi ki. Ez utóbbit még a hozzá kapcsolódó, rendkívül magas kockázat sem tudta „közömbösíteni” (lásd az 1. táblázat 3. oszlopában szereplő értékeket).

A fentiek alapján úgy tűnik, hogy a bitcoin sokkal inkább tekinthető a spekuláció, mint egy megalapozott, kiegyensúlyozott hozamot biztosító befektetési stratégia eszközének. A bitcoinba történő befektetés pozitív sajátosságának tudható be azonban, hogy hozama nem korrelál más eszközök (részvények, kötvények, árupiaci termékek, arany) hozamával. Ez a számos szerző által kimutatott tulajdonsága (lásd például Brière et al. 2015 és Misik 2018) a bitcoint alkalmassá teszi arra, hogy egy befektetési portfólióban más eszközök árfolyamcsökkenésének negatív hatását kompenzálja. Egyes tanulmányok rámutattak egy további kedvező sajátosságára is, nevezetesen arra, hogy növelni képes a befektetési portfólió hatékonyságát (Chen - Pandey 2014; Eisl et al. 2015; Misik 2018). Ezen azt kell érteni, hogy a bitcoin portfólióba történő bevonásával - az általunk is kimutatott magas egységnyi kockázatra eső hozama

\footnotetext{
${ }^{17}$ Pontosabban ez a mutató lehetővé teszi különféle, eltérő jövedelmezőséggel és kockázattal rendelkező befektetések teljesítményének összehasonlítását.

${ }^{18}$ Említésre érdemes, hogy Misik (2018) elemzésében ez a mutató az S\&P 500 részvényindex esetében 1,68nak bizonyult. A bitcoinra vonatkozóan az általa vizsgált periódusban ugyanakkor 13,07 nagyságú egységnyi kockázatra eső hozam értéket kapott.
} 
következtében - elérhető, hogy az így kapott befektetéskombináció adott kockázati szinthez tartozó hozama növekedjen.

\section{A bitcoin elterjedésének korlátai}

\subsection{Technológiai és energetikai korlátok}

A kriptovaluták jövőbeli felhasználását alapvetően korlátozza az Ethereum megalkotója, Buterin által megfogalmazott trilemma: a kriptovaluták esetében nem teljesülhet egyszerre az a hármas követelmény, hogy skálázhatók, decentralizáltak és biztonságosak. A skálázhatóságot megakadályozza a proof-of-work rendszer, ami limitálja a percenkénti tranzakciók számát. A biztonságot ugyan a decentralizáció biztosítaná, de a blokkméret növekedése és az egyre bonyolultabb számítási feladatok megoldása óhatatlanul elősegíti a bányászat, és ahogy az adatok mutatják, a kereskedelem centralizációját is (Roubini 2018).

A bitcoin-technológia létrehozásának legfőbb célja a tranzakciók biztonságának növelése volt oly módon, hogy ne kelljen megbízni egy pénzügyi közvetítóben, mint például a bankokban, mert maga a rendszer felépítése védi ki a csalásokat. Ezt a nyílt forráskód és a teljes blockchain visszaellenőrizhetősége biztosítja. A kezdeti időszakban ez talán így is volt, de mióta nem csak a cyber-libertariánusok és programozók szűk köre használja a kriptovalutákat, azóta ez az ellenőrzési lehetőség a 36 millió felhasználó számára illuzórikus. Nem egy - a társadalom, illetve a kormányzat által ellenőrzött - bankban kell megbízni a felhasználóknak, hanem a sokszor a legalitás határán mozgó, és ahogy a csődök és botrányok mutatják, akár pillanatok alatt eltűnő kriptovaluta-kereskedőkben, token-kibocsátókban és DApp-fejlesztőkben. Az Ethereum-platformon futó kódokban például 1000 soronként 100 hiba található (Gerard 2017:96). A kriptovaluták fejlesztése centralizált, maga a „kód a törvény” (Roubini 2018), de ez a kód bármikor megváltoztatható, és ebbe az egyszerű felhasználóknak nincs beleszólásuk. Maga a blockchain-rendszer sem védett a támadásoktól, és ha a rendszer 51 százaléka egy kézben összpontosul, akkor lehetőség nyílik arra, hogy visszamenőleg megváltoztassák a blokkokat (Farivar 2014).

A bitcoin-tranzakciók végrehajthatósága és gyorsasága attól függ, hogy van-e elég bányász, aki hitelesíti azokat. A bányászat pedig csak akkor éri meg, ha a költségei nem haladják meg a bitcoin adott piaci értékét. A bitcoin bányászatához felhasznált éves átlagos energia $61 \mathrm{TWh}^{19}$, ami a teljes magyar éves villamosenergia-felhasználás 130 százaléka (MAVIR 2019). A bitcoinnak a magas energiafelhasználáson kívül nincs semmilyen kapcsolata a valóságos gazdasági eseményekkel, hacsak nem vezeti be egy ország a bitcoint nemzeti valutaként és általános fizetőeszközként. Miután erre igen kevés az esély, ezért a bitcoin-bányászat során felhasznált villamosenergia

\footnotetext{
${ }^{19}$ https://cbeci.org/
} 
elvesztegetett energia, ami a társadalom és a jövő generációi számára kifejezetten károkat okoz. A bitcoin-infrastruktúrához szükséges hardver előállítása, az épületek felépítése, az energiaellátás kiépítése és a bányászat magas energiafelhasználása ugyanis még akkor is nagyon nagy környezeti terheléssel jár, ha a villamosenergiát megújuló forrásokból állítják elő. Nincsen olyan villamosenergia-termelés, ami ne károsítaná a környezetet, ne használna föl környezeti erőforrásokat és ne járulna hozzá a biodiverzitás csökkenéséhez.

\subsection{A szabályozási környezet kihívásai}

A kriptovaluták szabályozási környezete szinte országonként eltér, s a teljes tiltástól az engedélyezésig terjed. A világ két legnépesebb országa, Kína és India teljesen betiltotta a kriptovaluták használatát. A kínai kormány elkezdte a kriptovalutákat kiszolgáló infrastruktúra és ipar felszámolását is, aminek utolsó lépéseként környezetvédelmi okokra hivatkozva a kriptovaluták bányászatát is a nem kívánatos tevékenységek közé sorolta. Emellett a kínai központi bank saját kriptovaluta (CBDC - Central Bank Digital Currency) kibocsátását tervezi, ami nem egy decentralizált, peer-to-peer technológián alapuló digitális fizetőeszközt jelent, hanem a készpénz teljes kivonását és ezzel a pénzügyi tranzakciók, illetve a a lakosság összes tranzakciója ellenőrzésének a lehetőségét (Bloomberg 2018).

A teljes tiltással szemben találjuk azokat az országokat, ahol engedéllyel lehet kriptotőzsdéket üzemeltetni, ilyen például Japán, Dél-Korea vagy Luxemburg. Svájc különleges helyet foglal el, a Zug kantonban található Cripto Valley-ben adókedvezményekkel és egyéb támogatásokkal segítik a kriptovalutával, illetve blockchain-technológiával dolgozó start-upokat, amelyek 3000 embert foglalkoztatnak, és a legnagyobb 50 vállalatnak mintegy 44 milliárd dollár a piaci kapitalizációja (CVVC 2018).

A kriptovaluták kereskedelmében legnagyobb szerepet játszó USA és EU szabályozása még kiforratlan, visszatükrözi a bitcoin felhasználásának bizonytalanságait.

Az EU szabályozásának ${ }^{20}$ a középpontjában a pénzmosás megakadályozása áll, illetve előírja a kriptotőzsdék és kriptovalutával kapcsolatos szolgáltatások regisztrálását az adott országban. A pénzmosás lehetősége ugyan magától értetődőnek tűnik a kriptovaluták esetében, de a gyakorlatban egyelőre ez a kockázat alacsony, ahogy azt a brit kincstár kockázatértékelése is bemutatja (HM Treasury 2015). Az árfolyam változékonysága és bizonytalan likviditása miatt egyelőre nem éri meg pénzmosásra használni a kriptovalutákat. A bitcoin-tranzakciók anonimitása is csak látszólagos. A publikus főkönyvben kitörölhetetlenül megmarad minden tranzakció, s ugyanígy nyomot hagy az interneten is. A szabályzó hatóságok számára azonban nagy kihívás a pénzmosás elméleti lehetősége. A pénzmosás elleni harc klasszikusan a központi-

\footnotetext{
${ }^{20} 5$ th Anti-Money Laundering Directive (2018/1080/COD)
} 
lag ellenőrzött pénzintézetek ügyfélazonosítására épül. A kriptovaluták pénzmosási kockázatának csökkentése érdekében azonban új elveket és technológiai megoldásokat kell kidolgozni (Campbell-Verduyn 2018).

Magyarországon az EU-s direktívák implementálásán felül egyelőre nincs speciális szabályozás a kriptovalutákra. A Pénzügyminisztérium álláspontja szerint a bitcoin nem pénz (Fintechzone 2018), míg a Magyar Nemzeti Bank (MNB) felhívja a figyelmet a "fizetésre használható virtuális eszközök" magas kockázatára (MNB 2018).

\section{Van-e a bitcoinnak jövője?}

A bitcoinnal kapcsolatos vitákban gyakran felmerül az a tétel, miszerint a bitcoinnak nincs belső értéke (Brown 2019), a kriptovaluta valójában „puszta levegőre” épül. A bitcoin valóban nem használható fel semmilyen más célra, mint például az arany vagy egyéb kincsképző eszköz. A bitcoin ugyanis tiszta információ, és ebben a tekintetben betöltheti annak az abszolút pénznek a szerepét, ami nem kötődik semmilyen fizikai megtestesüléshez (Simmel 1900). Azonban ahhoz, hogy egy információ valóban pénz legyen, szükség van arra, hogy azt egy közösség elfogadja. Vagyis a pénzt nem a belső értéke teszi pénzzé, hanem az, ahogy a gazdasági szereplők értéket tulajdonítanak neki, ami így felfogható nem belső, hanem külső értéknek.

Mi az, ami a bitcoin-felhasználókat arra ösztönzi, hogy bitcoint, illetve más kriptovalutákat vásároljanak? Ez elsősorban a bitcoint körülvevő infrastruktúra, a ráépülő másodlagos szolgáltatások, amelyek lehetővé teszik bárki számára, hogy beszálljon, a bitcoinnal és kriptovalutákkal kapcsolatos hírek a médiában, a szabályozás bizonytalansága és a profitkilátások. A bitcoin ma elsősorban a rövid távú spekuláció eszköze, olyan befektetési eszköz, ami mögött a meglehetősen magas energia- és erőforrás-felhasználáson kívül semmilyen konkrét gazdasági folyamat és teljesítmény nincs. A bitcoint vásárlók számára egyetlen dolog fontos, az a hit, hogy a közeli vagy távolabbi jövőben lesznek olyanok, akiknek el tudják adni a kriptovalutájukat. Miután a bitcoin felhasználói nem köthetők egy-egy adott gazdasági közösséghez vagy országhoz, ezért az a potenciális felhasználóréteg, amelyik a jövőben fenntartja a kriptovalutákat, az internet-használók köréből kikerülve akár több milliárdra tehető.

A bitcoin vagy bármelyik decentralizált kriptovaluta általános fizetőeszközként részben a már idézett technológiai és biztonsági problémák miatt sem terjedhet el. Nehéz elképzelni továbbá egy olyan kormányt, amely feladja a pénzkibocsátás és ezzel együtt a monetáris szabályozás lehetőségét. Egy-egy vállalat számára pedig a bitcoin elfogadása óriási kockázattal jár, hiszen az árfolyam volatilitása akár percek alatt felörölheti a vállalat által alkalmazott árrést. 
Nem hanyagolható el a bitcoin hatása a pénzügyi eszközök fejlődésére (Kerényi Molnár 2017). A blokklánc-technológia bizonyos esetekben alkalmas lehet pénzügyi, gazdasági vagy akár társadalmi folyamatok nyomon követésére, a bitcoin által propagált digitális pénz eszméje pedig olyan új pénzügyi innovációkat generálhat, mint a Facebook által bevezetni kívánt, ám eddig meglehetősen nagy ellenállásba ütköző Libra, vagy a Wal-Mart által szabadalomra benyújtott dollár alapú digitális fizetőeszköz.

A bitcoin nem töltötte be azt a szerepet, amelyet Nakamoto szánt neki. Ennek az az oka, hogy az általa kifejlesztett szoftver-architektúra valójában technikai megoldást kínál fel bizonyos problémákra, de nem veszi figyelembe a pénzügyi tranzakciók mögötti gazdasági folyamatokat. A címben felvetett kérdésre válaszolva leszögezhetjük, hogy a bitcoin a mostani formájában nem alkalmas arra, hogy általánosan elfogadott fizetőeszközzé váljon. A blockchain-technológiába beépített biztonsági rendszer lelassítja a tranzakciók átfutási idejét, s így nem veheti fel a versenyt az elterjedt pénzügy-technológiai megoldásokkal. A bitcoin-iparág szolgáltató cégei (a tőzsdék, pénztárca-szolgáltatók) a legalitás határán mozognak, bármelyik pillanatban eltűnhetnek, vagy állami beavatkozással megszüntethetik őket. A legtöbb országban nincs megfelelő szabályozás a tevékenységüket illetően, így a felhasználók, illetve befektetők semmilyen védelemre nem számíthatnak. A bitcoin több mint egy évtizedes története azt mutatja, hogy bár széleskörü elterjedése nem történt meg, de egy szűk piaci szegmensben kockázatos befektetési eszközként fennmaradhat.

\section{Felhasznált irodalom}

András Bence (2019): Hát nem arról volt szó, hogy összeomlik a bitcoin? Portfolio.hu - Online gazdasági újság, augusztus 5. https://www.portfolio.hu/prof/20190805/hat-nem-arrolvolt-szo-hogy-osszeomlik-a-bitcoin-333275. Letöltés ideje: 2019. augusztus 5.

Antonopoulos, A.M. (2016): Mastering Bitcoin (ford. Bitcoin fejlesztőknek). https:// bitcoinbook.info/wp-content/translations/hu/book.pdf. Letöltés ideje: 2019. július 14.

Bánfi Ziád (2018): A bitcoinról pénzelméleti szempontból. Gazdaság és Pénzügy, 5(1): 2-30.

Bloomberg (2018): China's Plan to Sideline Bitcoin. https://www.bloomberg.com/news/ articles/2018-12-13/china-s-plan-to-sideline-bitcoin. Letöltés ideje: 2019. augusztus 5.

Brenda, G. - Alun, J. (2019): China wants to ban bitcoin mining. https://www.reuters.com/ article/us-china-cryptocurrency/china-wants-to-ban-bitcoin-mining-idUSKCN1RLOC4. Letöltés ideje: 2019. augusztus 5.

Brière, M. - Oosterlinck, K. - Szafarz, A. (2015): Virtual currency, tangible return: Portfolio diversification with bitcoin. Journal of Asset Management, 16(6): 365-373. https://doi. org/10.1057/jam.2015.5 
Brown, C. (2019): Bitcoin Has No Intrinsic Value - and That's Great. (n.d.). https://medium.com/coinmonks/bitcoin-has-no-intrinsic-value-and-thats-great-e6994adbfe0f. Letöltés ideje: 2019. augusztus 5.

Buttyán Levente - Vajda István (2012): Kriptográfia és alkalmazásai. Typotex.

Campbell-Verduyn, M. (2018): Bitcoin, Crypto-Coins, and Global Anti-Money Laundering Governance. Crime, Law and Social Change, 69(2): 283-305. https://doi.org/10.1007/ s10611-017-9756-5

Chen, W.Y. - Pandey, V. K. (2014): The value of bitcoin in enhancing the efficiency of an investor's portfolio. Journal of Financial Planning, 27(9): 44-52.

Chohan, U. W. (2017): Assessing the Differences in Bitcoin \& Other Cryptocurrency Legality across National Jurisdictions. School of Business and Economics, University of New South Wales, Canberra Discussion Paper. https://doi.org/10.2139/ssrn.3042248

CVVC (2018): The Crypto Valley's Top 50 Technology Partner. The Blockchain Industry in Switzerland \& Liechtenstein analyzed and visualized. https://www.coinpro.ch/wp-content/ uploads/2019/07/CVVC-Top50-H1-2019.pdf. Letöltve: 2020. február 3.

Eisl, A. - Gasser, S. - Weinmayer, K. (2015): Caveat emptor: Does bitcoin improve portfolio diversification? SSRN Electronic Journal. https://doi.org/10.2139/ssrn.2408997

Emsley, J. (2019): Alleged Bitcoin Ponzi scheme Plus Token could be liquidating billions of dollars in stolen crypto, says VC. https://cryptoslate.com/alleged-bitcoin-ponzi-schemeplus-token-could-be-liquidating-billions-of-dollars-in-stolen-crypto-says-vc/. Letöltés ideje: 2019. augusztus 24 .

Farivar, C. (2014): Bitcoin pool GHash.io commits to $40 \%$ hashrate limit after its $51 \%$ breach. Ars Technica, 16 July.

Fintechzone (2018): A Pénzügyminisztérium válasza a kriptovaluták szabályozásával kapcsolatban. https://fintechzone.hu/a-penzugyminiszterium-valasza-a-kriptovalutak-szabalyozasaval-kapcsolatban/. Letöltés ideje: 2019. augusztus 24.

Gábor Tamás - Kiss Gábor Dávid (2018): Bevezetés a kriptovaluták világába. Gazdaság és Pénzügy, 5(1): 31-65.

Gerard, D. (2017): Attack of the 50 Foot Blockchain: Bitcoin, Blockchain, Ethereum \& Smart Contracts. CreateSpace Independent Publishing Platform.

Golumbia, D. (2016): The Politics of Bitcoin Software as Right-Wing Extremism. University of Minnesota Press. 
HM Treasury (2015): UK national risk assessment of money laundering and terrorist financing. Her Majesty's Treasury and Home Office. https://assets.publishing.service.gov.uk/government/uploads/system/uploads/attachment_data/file/468210/UK_NRA_October_2015_final_web.pdf. Letöltés ideje: 2020. január 12.

Kathi Ferenc (2009): Hash függvények. Szakdolgozat, Debreceni Egyetem Informatikai Kar. https://dea.lib.unideb.hu/dea/bitstream/handle/2437/90313/Szakdolgozat_KathiFerenc. pdf;jsessionid=B66004CEDC6B420308BC16C17D65FFA1?sequence=1. Letöltés ideje: 2019. december 12.

Kerényi Ádám - Molnár Júlia (2017): A FinTech-jelenség hatása - Radikális változás zajlik a pénzügyi szektorban? Hitelintézeti Szemle, 16(3): 32-50. http://doi.org/10.25201/ HSZ.16.3.3250

Levin, M.R. (2009): Liberty and Tyranny: A Conservative Manifesto. New York: Simon and Schuster.

MAVIR (2019): A teljes bruttó energiafelhasználás megoszlása. http://www.mavir.hu/ documents/10258/229275463/Előzetes+Termelésmegoszlás++2018+MavirHonlapra+HU+20190131.pdf. Letöltés ideje: 2019. július 12.

Misik Sándor (2018): A bitcoin a portfólióelmélet tükrében. Gazdaság és Pénzügy, 5(1), 66-73.

MNB (2018): Az MNB kockázatosnak tartja a fizetésre használható virtuális eszközöket, például a Bitcoint. Sajtóközlemény, Magyar Nemzeti Bank. https://www.mnb.hu/archivum/ Felugyelet/root/fooldal/topmenu/sajto/sajtokozlemenyek/bitcoin_kozl. Letöltés ideje: 2019. július 12 .

Mullins, E.C. (1992): The World Order: Our Secret Rulers. Published by Ezra Pound Institute of Civilization, Staunton, VA.

Nakamoto, S. (2008): Bitcoin: A Peer-to-Peer Electronic Cash System. White paper. 1-9. https://bitcoin.org/bitcoin.pdf. Letöltés ideje: 2019. április 15.

Roubini, N. (2018): Crypto is the Mother of All Scams and (Now Busted) Bubbles. While Blockchain Is The Most Over-Hyped Technology Ever, No Better than a Spreadsheet/Database. https://www.banking.senate.gov/imo/media/doc/Roubini\%20Testimony\%2010-11-18.pdf. Letöltés ideje: 2019. július 12.

Rothbard, M. (2002): A History of Money and Banking in the United States: The Colonial Era to World War II. Auburn, Ala.: Mises Institute.

Simmel, G. (1900): Philosophie des Geldes. Leipzig: Duncker\&Humboldt Verlag. 
Tassev, L. (2019): The Number of Cryptocurrency Wallet Users Keeps Rising. https://news. bitcoin.com/the-number-of-cryptocurrency-wallet-users-keeps-rising/. Letöltés ideje: 2019. augusztus 14 .

Tuwiner, J. (2019): Bitcoin Mining in China. https://www.buybitcoinworldwide.com/mining/ china/. Letöltés ideje: 2019. augusztus 14. 